http://heanoti.com/index.php/hn

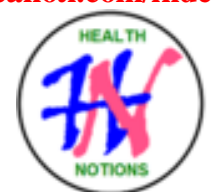

RESEARCH ARTICLE

URL of this article: http://heanoti.com/index.php/hn/article/view/hn30402

\title{
Endhorpin Massage and Pregnancy Exercise as a Method to Relieve Lower Back Pain in
} Trimester III Pregnant Women

\author{
Yusni Podungge ${ }^{1(\mathrm{CA})}$ \\ ${ }^{1(\mathrm{CA})}$ Lecturer of Midwifery Department, Health Polytechnic of Gorontalo, Indonesia; nunifay@ yahoo.co.id \\ (Corresponding Author)
}

\begin{abstract}
Pregnancy is a happy thing for every husband and wife but sometimes complaints arise during pregnancy, one of them that is very annoying is back pain problems when pregnant. Back pain when pregnant is usually experienced by women in certain time of the pregnancy, usually happens often in trimester 3 pregnancy. The purpose of this research is to know the difference of pregnancy exercise effectiveness with endhorpin message to decrease in lower back pain in trimester III pregnancy at Sipatana Public Health Center. This research type was quasi experiment by using the method of pre and post test with two group design. The total samples were 30 people. The result of bivariate analysis was pregnancy exercise $(p=0.000)$ and endhorpin message $(p=0.000)$ which $(p<0.05)$, so that there was an effect of doing pregnancy exercise and endhorpin message to decrease in lower back pain in Trimester III pregnancy. The difference of effectiveness between pregnancy exercise and endhorpin massage is $(\mathrm{p}=0.042)$, so that there is a significant difference between doing pregnancy exercise and back massage to decrease in lower back pain in trimester III pregnancy at working area of Sipatana Public Health Center. It is expected that Trimester III pregnant women can apply pregnancy exersice and back massage in order to be healthy especially decrease lower back pain in pregnancy.
\end{abstract}

Keywords: Pregnancy, Endhorpin, Massage, Lower back

\section{INTRODUCTION}

\section{Background}

Pregnancy is a meeting between sperm and ovum, the period of pregnancy starts from conception until the birth of the baby. Changes that occur during pregnancy are often a complaint for pregnant women including nausea and vomiting in early pregnancy, constipation, varicose veins, voiding disorders, hemorrhoids, and swelling of the legs and feet and back pain ${ }^{(1)}$. Pregnancy is also happy for every husband and wife but sometimes complaints arise during pregnancy, one of which is very disturbing is the problem of back pain when pregnant. Back pain during pregnancy is usually experienced by women at certain times during their pregnancy, usually often in third trimester of pregnancy ${ }^{(2)}$. About $80 \%$ of women will experience back pain at some point during pregnancy ${ }^{(3)}$.

Based on data from the Gorontalo City Health Office, the number of pregnant women in each working area of Public Health Center in Gorontalo City in 2017 is Pilolodaa Public Health Center 135, Buladu Health Center 170, Dungingi Health Center 348, Limba B Health Center 349, Tamalate Public Health Center 408, Hulonthalangi Health Center 322, Dumbo Health Center Raya 271, Wongkaditi Public Health Center 261, Dulalowo Public Health Center 472, and Sipatana Public Health Center 252 $2^{(4)}$.

Based on the initial survey of pregnant women in February 2018 at the Sipatana Health Center in Gorontalo City, researchers interviewed 7 trimester III pregnant women that 5 of them experienced back pain which was very disturbing while carrying out their activities and 2 pregnant women complained of back pain not disturbing activities. Efforts to reduce back pain vary, in general, the mother overcomes her back pain by massaging her back with white wood oil, resting and reducing heavy work. After being asked the pregnant woman does not know the benefits of endorphin massage which can reduce or relieve pain or back pain in the mother get pregnant so that when giving birth can improve the relaxed conditions in the body of pregnant women. 
The activity has not been widely implemented in Gorontalo, but some Public Health Center have implemented this pregnancy exercise program on maternal class programs, for example at the Sipatana Health Center, for which researchers are interested in conducting research on differences in effectiveness between pregnant gymnastics and endorphin massage backs for decreasing lower back pain in pregnancy trimester III in the working area of Sipatana Public Health Center.

\section{METHODS}

This study included the type of quasi experiment by using the method of pre and post-test with two group design where researchers would analyze the differences in effectiveness between pregnancy exercise and endothelial massage against lower back pain in the third trimester of pregnancy in the working area of Sipatana Public Health Center. This study conducted in working area Sipatana Public Health Center on $5^{\text {th }}$ Septermber till $5^{\text {th }}$ Oktober 2018. The population of this study was all trimester III pregnant women in the working area of Sipatana Health Center with a total of 63 people. The study sample was a third trimester pregnant woman who experienced low back pain. The sampling technique in this study was a purposive sample method with inclusion criteria, namely third trimester pregnant women who experienced low back pain, mothers who were willing to become respondents, and uncomplicated pregnant women. In this study the measuring instrument used was the scale of VAS pain function to determine the scale of pain before (pre-test) and after (post-test) pregnancy exercise intervention and end-massage massage. The statistical test used was the Two Related Sample Wilcoxon-test non-parametic statistical test.

\section{RESULTS}

\section{Descriptive of Level Back Pain}

Table 1. Distribution of back pain before being given pregnancy gymnastics in Sipatana Public Health Center

\begin{tabular}{ccc}
\hline Level of pain & Frequency & Percentage \\
\hline Light pain & 2 & 10.0 \\
Moderate pain & 20 & 90.0 \\
Total & 22 & 100.0 \\
\hline
\end{tabular}

Based on the table above, it is known that before pregnancy exercise, 22 pregnant women experience moderate pain $(100 \%)$.

Table 2. Distribution of back pain after being given pregnant gymnastics in Sipatana Public Health Center

\begin{tabular}{ccc}
\hline Level of pain & Frequency & Percentage \\
\hline Light pain & 17 & 77.3 \\
Moderate pain & 5 & 22.7 \\
\hline Total & 22 & 100.0 \\
\hline
\end{tabular}

Based on the table above, it is known that the level of back pain after pregnancy exercise was at the level of light pain $(77.3 \%)$.

Table 3. Distribution of back pain before being given endhorpin massage in Sipatana Public Health Center

\begin{tabular}{ccc}
\hline Level of pain & Frequency & Percentage \\
\hline Light pain & 1 & 10.0 \\
Moderate pain & 21 & 90.0 \\
\hline Total & 22 & 100.0
\end{tabular}

Based on the table above, it is known that 20 pregnant women experience moderate pain before being given an endhorpin massagge. Along with increasing gestational age, trimester III pregnant women often experience complaints of lower back pain. This pain is one of the discomforts in the third trimester of pregnancy. 
Table 4. Distribution of back pain after being given endhorpin massage in Sipatana Public Health Center

\begin{tabular}{ccc}
\hline Level of pain & Frequency & Percentage \\
\hline Light pain & 1 & 4.5 \\
Moderate pain & 21 & 95.5 \\
\hline Total & 22 & 100.0 \\
\hline
\end{tabular}

Based on the table above, it is known the level of back pain of respondents, most of them are at the level of moderate pain $(95.5 \%)$.

Table 5. Differences in levels of lower back pain before and after pregnancy exercise in pregnancy trimester III in Sipatana Public Health Center

\begin{tabular}{cccccc}
\hline \multirow{2}{*}{ Back pain level } & \multicolumn{2}{c}{ Pre test } & \multirow{2}{*}{ Back pain level } & \multicolumn{2}{c}{ Post test } \\
\cline { 2 - 3 } & $\mathrm{f}$ & $\%$ & & $\mathrm{f}$ & $\%$ \\
\hline Light pain & 2 & 10.0 & Light pain & 17 & 77.3 \\
Moderate pain & 20 & 90.0 & Moderate pain & 5 & 22.7 \\
\hline Total & 22 & 100.0 & Total & 22 & 100.0 \\
\hline
\end{tabular}

Based on the table above, respondents with the highest level of pain before being given pregnancy exercise are at the level of moderate pain as many as (90\%) and 2 respondent (10\%) were at the level of light pain. After being given pregnancy exercise (77.3\%) experienced light pain. This showed that respondents experienced a decrease in the level of pain.

Table 6. Differences in level of lower back pain before and after back massage in pregnancy trimester III in Sipatana Public Health Center

\begin{tabular}{|c|c|c|c|c|c|}
\hline \multirow{2}{*}{ Back pain level } & \multicolumn{2}{|c|}{ Pre test } & \multirow{2}{*}{ Back pain level } & \multicolumn{2}{|c|}{ Post test } \\
\hline & $\mathrm{f}$ & $\%$ & & $\mathrm{f}$ & $\%$ \\
\hline Light pain & 1 & 4.5 & Light pain & 1 & 90.0 \\
\hline Moderate pain & 21 & 95.5 & Moderate pain & 21 & 10.0 \\
\hline Total & 22 & 100.0 & Total & 22 & 100.0 \\
\hline
\end{tabular}

Based on the table above, after an endorpin massagge, 1 respondent $(4.5 \%)$ who did not experience a decrease in back pain with light pain. One of the factors that can cause back pain is parity, namely first parity and more than three children. Especially if accompanied by the age risk factor of the respondent. Pregnant women will experience more discomfort and the risk of lower back pain will increase. In this study, one respondent who did not experience pain reduction was affected by the age of 30 years, was first pregnant and had an entrepreneurial job.

\section{Analysis of Comparison of Lower Back Pain in Pregnancy Trimester III}

Table 7. Comparison of lower back pain in pregnancy trimester III before and after given pregnancy gymnastics in Sipatana Public Health Center

\begin{tabular}{ccccc}
\hline Variable & Total & Mean & SD & Sig \\
\hline Back Pain & & & & \\
Pre Test & 22 & 4.68 & 0.780 & 0.000 \\
Post Test & 22 & 3.27 & 0.935 & \\
\hline
\end{tabular}

Table 7 showed that average lower back pain before being given the treatment of pregnancy exercise (pre test) were 4.68 and the average after being given the treatment of pregnancy exercise (post test) was 3.27. This means that after being given pregnancy exercise, the respondent's pain level has decreased. The results of the statistical test with the Wilcoxon-test obtained a Sig 0.000 value ( $p<0.05)$, meaning that there is an effect of giving pregnant gymnastics to decrease lower back pain in the third trimester of pregnancy in the working area of Sipatana Public Health Center. 
Table 8. Comparison of lower back pain in pregnancy trimester III before and after given endhorpin massage in Sipatana Public Health Center

\begin{tabular}{crrrc}
\hline Variable & Total & Mean & SD & Sig \\
\hline Back pain & & & & \\
Pre test & 22 & 4.91 & 1.019 & 0.000 \\
Post test & 22 & 2.64 & 0.790 & \\
\hline
\end{tabular}

Based on the table above, the results of the average low back pain before endhorpinmassage (pre test) were 4.91 and the average after endothelial massage (post test) was 2.64. This means that after being given pregnancy exercises there was a decrease in lower back pain. The results of the statistical test with Wilcoxontest obtained a Sig. 0.000 value $(\mathrm{p}<0.05)$, meaning that there was a difference between the level of lower back pain in third trimester pregnant women before and after endorphous massage.

Table 9. Effectiveness differences between pregnancy gymnastics and back massage on decreasing lower back pain in pregnancy trimester III in Sipatana Public Health Center

\begin{tabular}{cccc}
\hline Treatment type & Mean rank & Mann-Whitney U & Sig (2-tailed) \\
\hline Pregnancy exercise & 25.00 & \multirow{2}{*}{187.000} & 0.042 \\
Back massage & 20.00 & & \\
\hline
\end{tabular}

Based on the table above, the Sig or p-value of 0.042 is smaller than $\alpha=0.05(0.042<0.05)$. This means that there is a significant difference between giving pregnant gymnastics and back massage to decrease low back pain in the third trimester of pregnancy in the work area of the Sipatana Health Center.

\section{DISCUSSION}

Based on Table 7 shows the results of the average lower back pain before being given the treatment of pregnant gymnastics (pre-test) is 4.68 and the average after being given the treatment of pregnancy exercise (post-test) is 3.27. This means that after being given pregnancy exercise, the respondent's pain level has decreased. The results of the statistical test with the Wilcoxon-test obtained a Sig 0.000 value $(p<0.05)$, meaning that there is an effect of giving pregnant gymnastics to decrease lower back pain in the third trimester of pregnancy in the work area of the Sipatana Health Center. Lower back pregnancy pain is a clinical syndrome characterized by the main symptoms of pain or other unpleasant feelings in the back of the body from the last rib to the buttocks or anus due to the influence of hormones which cause interference with the basic substance of the support and connective tissue resulting in decreased elasticity and flexibility of muscles, besides that it is also caused by mechanical factors that affect the curvature of the spine by changing attitudes and increasing the burden when pregnant. This low back pain can be felt at all levels of pregnancy, but most are felt during the second and third trimester of pregnancy.

Back pain occurs because of changes in pregnancy hormones that increase relaxin hormone levels, this affects the flexibility of ligament tissue which ultimately increases joint mobility in the pelvis and will affect spinal and pelvic instability and cause discomfort ${ }^{(5)}$. The pain response at a mild level is that the respondent feels pain, can hold it back and can still communicate well. While at the level of moderate pain, the respondent felt that the pain was disturbing and tried to be able to hold it back, and could respond to commands properly. Pain is a subjective matter, so that only people who experience this condition can describe the level of pain that is felt. This condition will affect the decrease in pain score in each respondent ${ }^{(6)}$.

Predisposing factors for back pain during pregnancy include weight gain during pregnancy, rapid changes in posture, previous back pain, repeated stretches, increased levels of relaxin hormones. To alleviate lower back pain that is often felt by pregnant women, several One of the things that is mild exercise is pregnancy exercise. Pregnant exercise is a form of physical activity that is beneficial because it develops body muscles, increases the elasticity of the pelvic and ligament muscles and decreases the incidence of bleeding during and after delivery and can reduce the incidence of fetal distress ${ }^{(7)}$. For that you need to be given training or sports such as pregnancy exercise.

Pregnancy exercise is a relaxation exercise performed by pregnant women since the age of 28 weeks with a duration of 30 minutes and at least once a week, with increasing weight and enlarging the stomach can change the posture so the center of gravity the body shifts forward, the back muscles tend to shorten if the abdominal muscles stretch so that it can cause imbalances and additional stress can be felt in the back area, therefore the need for muscle training or relaxation through pregnancy exercises. Pregnant gymnastics on decreasing lower back pain in third trimester pregnant women by showing a p-value of $0.038<0.05$, so that $\mathrm{H}_{\mathrm{o}}$ is rejected and $\mathrm{Ha}$ is accepted which means there is influence before and after pregnancy exercise ${ }^{(8)}$. 
From this study the authors analyzed that pregnant gymnastics can reduce back pain in pregnant women because after interviewing the mother's questionnaire obtained before the mother did pregnancy exercise the mother experienced back pain and after the mother did pregnancy exercise back pain experienced by the mother experienced a decrease. The results of this study are also in line with the research on the effectiveness of pregnant gymnastics on decreasing back pain in pregnant women which states that pregnancy exercise is effective against decreasing back pain in pregnant women.

Back pain experienced by pregnant women certainly can not be left alone. Therefore, a health worker must provide counseling or information to pregnant women who experience discomfort such as back pain can be recommended to do light exercise, namely pregnancy exercises to reduce discomfort and maintain health during pregnancy. From the results of the study said that the support given by many people in the form of motivation to attend pregnancy exercises and delivered by family or husband to come to the gym, pregnant, but some of them said that the interest to participate in pregnancy exercise classes will be reduced (lazy) if the support given from the surrounding people is reduced, not only that, just seeing from a considerable distance to be taken by participants can be the influence of the participants to attend the event.

Factors that influence a person's interests are social support, gender, leisure, age, education level and level of socio-economic status. So with the explanation above, researchers assume that interest is related to the social support given by people around the interests of pregnant women in pregnancy exercises. This was supported by Susanto.A's statement, 2013 that this interest was greatly influenced by the environment, parents' encouragement, customs or habits of the people around them.

Based on Table 8, the results of the average lower back pain before given endhorpinmassage (pre test) were 4.91 and the average after giving endhorpin massage (post test) was 2.64. This means that after being given pregnancy exercises there was a decrease in lower back pain. The results of the statistical test with Wilcoxon-test obtained a Sig. 0.000 value $(p<0.05)$, meaning that there was a difference between the level of lower back pain in third trimester pregnant women before and after endorphous massage. Based on the results of the study, the average value of lower back pain before and after the endorsement of massage respondents decreased the level of pain. That is, giving endorphin massage for 30 minutes affected the level of lower back pain in the third trimester of pregnancy in the Sipatana Health Center work area. A massage effect on decreasing back pain in third trimester pregnant women. Back massage is the movement of gently wiping the back, the sequencing can be short and long movements with all palms that have been flattened for 30 minutes which aims to increase muscle relaxation, soothe the ends nerve endings, and eliminate pain. The main action of back massage is considered to close the gate to inhibit the travel of pain stimuli at a higher center ${ }^{(9)}$.

Basically, the body also has a substance that is able to inhibit pain, namely endorphins and enchefalin which can relieve pain. The degree of one's reaction to pain varies greatly. This condition is partly due to the ability of the brain itself to suppress the amount of pain signals that enter the nervous system, namely by activating a pain regulating system, called the analgesia system. It is believed that the main function of endorphins is to attach to the brain's opioid receptors, relieve physical pain. At the same time, endorphins also increase comfort. Pregnant women can prevent discomfort in the form of back pain through good posture and body mechanics and avoid fatigue.

Based on Table 9, the Sig or p-value of 0.042 is smaller than $\alpha=0.05(0.042<0.05)$. This means that there is a significant difference between giving pregnant gymnastics and back massage to decrease low back pain in the third trimester of pregnancy in the work area of the Sipatana Health Center. Exercise that is done regularly by paying attention to the frequency and duration of 30 minutes at least once a week can help relax the circulation of blood and make stiff muscles flexible, and reduce discomfort or pain. While giving back massage with regular movements for 30 minutes is also expected to increase relaxation and comfort felt by pregnant women. Both of these techniques (pregnancy exercise and back massage) can release endorphins which are natural pain relievers, so that they can blockade pain so that it is effective for reducing lower back pain felt by pregnant women.

In this study, 22 respondents were given pregnant gymnastics and endorsement massage, all respondents measured the level of pain before being given treatment, then measured again the level of pain after being treated. From the results of the study, respondents experienced a significant reduction in pain can be seen from the mean rank value for decreasing the level of lower back pain in respondents who were given pregnancy exercise at 19.00 while on the back massage the mean rank value decreased lower back pain as low as 12.00 , this means back massage more effective in lowering lower back pain than pregnancy exercise.

Massage has a distracting effect that can stimulate opiate receptors in the brain and spinal cord. The central nervous system secretes endogenous opiates (endorphins) in the descending control system. An obstetrician, Constance Palinsky, was moved to use endorphins to reduce or alleviate pain in mothers who will give birth. Endorphin massage is created, which is a technique of light touch and massage, which can normalize heart rate and blood pressure, and improve the relaxed condition of the body of pregnant women by triggering a feeling of comfort through the surface of the skin. Evidently from the results of the study, this technique can increase the release of oxytocin, a hormone that facilitates labor ${ }^{(10)}$. 
Endorphin massage is a therapy that is quite important given to pregnant women in the time leading up to the time of delivery. This massage can stimulate the body to release endorphins which are pain relievers and can create a feeling of comfort. During this time, endorphins have been known as substances that have many benefits. Some of them are regulating the production of growth hormones and sex, controlling pain and persistent pain, controlling feelings of stress, and emergence through various activities, such as deep breathing and relaxation, and meditation. Endorphine is produced by doing activities such as meditation, deep breathing, or through acupunture treatment. Endorphine is believed to produce four keys to the body and mind: namely increasing the immune system, reducing pain, reducing stress (anxiety), and slowing down the aging process ${ }^{(11)}$.

Pregnant exercise is basically the same as other sports or fitness exercises that can produce relaxation. Movement found in pregnancy exercises can strengthen the abdominal muscles so as to prevent excessive tension which causes the intensity of back pain to decrease. In addition, conducting pregnancy exercises can release endorphin hormones in the body, where endorphin hormones function as tranquilizers and are able to reduce lower back pain during pregnancy but pregnancy exercises have special rules and have other supporting conditions such as instructors, places and medical recommendations from doctors. or midwife. So that it can be concluded that, pregnancy exercise is not not directly in dealing with pain ${ }^{(12)}$.

Pregnant exercise can reduce back pain because in the pregnancy exercise there is a movement that can strengthen the abdominal muscles, when the ligaments around the pelvis tighten and do not provide strong support to the joints the muscles become the second line of defense to help prevent excessive tension in the pelvic ligaments. Efforts made to treat lower back pain in pregnancy, namely distributing pregnant gymnastics leaflets and back massage, then provide an explanation that perceived back pain is a normal condition caused by various causes, including due to abdominal enlargement, wrong postures due to daily activities, and stress. Explain that back massage can be done by anyone, and anytime when back pain is felt. Advice on adequate and regular rest, drinking warm water, not lifting heavy objects, and not using high heels.

\section{CONCLUSION}

The results of this study are a decrease in lower back pain after pregnancy exercise in pregnancy Trimester III, a decrease in lower back pain after endorpin massage in TrimesterIII pregnancy and there is a difference in effectiveness between pregnancy exercise and endhorpin massage in pregnancy Trimester III in the Working Area of Sipatana Public Health Center.

\section{REFERENCES}

1. Saha. Effect of Pregnancy Gymnastics on Back Pain in Trimester III Pregnant Women at Pilolodaa Health Center (Pengaruh Senam Hamil terhadap Nyeri Punggung pada Ibu Hamil Trimester III di Puskesmas Piloloda). Undergraduate Thesis. Poltekkes Gorontalo. 2016.

2. Kartikasari N. Effect of Endorphin Massage on Decreasing Intensity of Back Pain in Pregnant Women (Pengaruh Endorphin Massage terhadap Penurunan Intensitas Nyeri Punggung Ibu Hamil). Rakernas Aipkema. 2016.

3. Juliarni. Actions of Pregnant Women Overcoming Back Pain During Pregnancy Trimester III at Hj Clinic. Medan Ramini 2013 (Tindakan Ibu Hamil Mengatasi Nyeri Punggung Saat Kehamilan Trimester III di Klinik Hj. Ramini Medan Tahun 2013). Scientific Report. FKp-USU. 2013.

4. Dinkes Kota Gorontalo. Health Profile of Gorontalo City (Profil Kesehatan Kota Gorontalo). Gorontalo: Dinkes Kota Gorontalo; 2018.

5. Braxshaw E. Pregnancy and Postpartum Gymnastics (Senam Hamil dan Nifas). Jakarta: EGC; 2007.

6. Solehati dkk. The Concept and Application of Relaxation in Maternity Nursing (Konsep dan Aplikasi Relaksasi dalam Keperawatan Maternitas). Bandung: Refika Aditama; 2015.

7. Widiant A. Health Gymnastics of Gymnastics Applicatin for Health (Senam Kesehatan Aplikasi Senam untuk Kesehatan). Yogyakarta: Nuha Medika; 2010.

8. Alloya A. Different Effect of Pregnant Gymnastics with Warm Compresses and Massage on Decreasing Lower Back Pain in Trimester III Pregnant Women (Beda Pengaruh Antara Senam Hamil Dengan Kompres Hangat Dan Massage Terhadap Penurunan Nyeri Punggung Bawah Pada Ibu Hamil Trimester III). Undergraduate Thesis. FIK-UMS; 2016.

9. Aini L. Differences in Effleurage and Warm Compress Against Decreased Back Pain in Trimester III Pregnant Women (Perbedaan Masase Effleurage dan Kompres Hangat Terhadap Penurunan Nyeri Punggung Pada Ibu Hamil Trimester III). Mojokerto: Akper Dian Husada Mojokerto. Jurnal Keperawatan dan Kebidanan. 2016.

10. Mongan M. Hypno Birthing: Safe, Easy and Comfortable Discharge Method (Hypno Birthing: Metode Melahirrkan Secara Aman, Mudah dan Nyaman). Jakarta: PT Bhuana Ilmu Populer; 2009. 
11. Kartikasari N. Effectiveness of Endorphine Massage on Primipara Maternal Mothers' Anxiety Level (Pengaruh Endorphin Massage terhadap Penurunan Intensitas Nyeri Punggung Ibu Hamil). Rakernas Aipkema. 2016.

12. Sukmaningtyas W, Windiarti PA. Effectiveness of Endorphine Massage on Primipara Maternal Mothers' Anxiety Level (Efektivitas Endorphine Massage terhadap Tingkat Kecemasan Ibu Bersalin Primipara). Bidan Prada: Jurnal Publikasi Kebidanan Akbid YLPP Purwokerto. 2016;7(1):53-62. 